\title{
Linguistic brand management of tourist destination
}

\author{
Vera A. Mityagina - Elina Yu. Novikova - Emilia Charfaoui - Jarmila \\ Opalkova
}

DOI: 10.18355/XL.2018.11.02.44

\begin{abstract}
This article considers linguosemiotic signs of tourist destination branding which provide for the formation of a region's positive image. The creation of a tourist brand is presented as a system of consecutive communicative actions within multilingual, multi-genre, discursively variative, terminologically and toponimically normalized and regionally specified tourism discourse. The authors pay special attention to the analysis of branding axiology and brand naming strategies in tourism discourse.

Key words: branding, brand, tourist destination, city-management, linguistic brand management, naming, slogan
\end{abstract}

\section{Introduction}

The XXI century globalization with tourism being one of its basic factors erases national and cultural boundaries between countries and reveals new opportunities for understanding one's own identity and others' socio-cultural experience.

Tourism has become a favorite pastime reflecting a new quality of the society's life as well as an important industry. Choosing a certain region, area or destination by a tourist is based on several significant factors which are the personal interest and a set of a person's needs depending on feedback, recommendations and public opinion in general. The image of a specific tourist destination resulting from a purposeful creation of a positive and appealing picture of a city or region worth visiting plays an important role in making it attractive.

A transparent and interesting brand reflecting the key features of a region, city or area is an important component of a destination image. Various brand formation researches are carried out by Western researchers, and some of them to be specially mentioned are S. Anholt, C. Burmann, S. Zeplin, Gert-Jan Hospers, M. Florek, A. Insch, J.Gnoth, J. Hildreth, K. Dinnie. Russian and Slovak place branding researchers study basic questions of the places' image as well as specific regional brands (B.R. Asadov, I.A. Vasilenko, A.I. Kubyshkin, A.N. Lyulko, N.A. Tsvetkova, E.Y. Tsumarova, M.V. Yakovlev, V. Horvath, D. Lehotska, J. Pleva, R. Matlovic, K. Matlovicova, B. Nemethyova, R. Paulickova).

Place branding has become one of the most popular subjects in marketing research. The study of this phenomenon as well as the terminological nominations of the relevant notions were pioneered by British political scientist Simon Anholt who has been widely publishing papers on place and national branding since 2002 (Anholt 2007, 2009). His national brand evaluation system considering such development trends as tourism, export, people, culture, investment, immigration as well as his notion of competitive identity expanded the concept of national branding up to the idea of the Good Country Index influencing the formation of a country's brand image, national identity and reputation. The notion of brand has not yet received a comprehensive and systemic linguistic interpretation. It is noteworthy that the verbal component of place marketing is one of the crucial ones in the formation of a country's / region's / city's tourist attractive image.

XLinguae, Volume 11, Issue 2, April 2018, ISSN 1337-8384, eISSN 2453-711X 


\section{Research objective and material}

The understanding of place branding from the point of marketing is presented in papers by many European researchers. For example, the monograph Marketing Places Europe: How to Attract Investments, Industries, Residents and Visitors to Cities, Communities, Regions and Nations in Europe by P. Kotler, K. Asplund, I. Rein and D. Haider (Kotler and others 2005) presents an idea of today's people becoming consumers and places (cities, regions and countries) becoming goods.

If you follow the marketers' and economists' stance that place branding helps create an impression about a region by using all available tools, then brand formation research should be done considering the following statements:

1. The formation of a region's image in the minds of tourists is achieved through the use of effective communicative semiosis signs with one of such signs being the text;

2. The study of the nominative formation and work of onomastic and terminological units of regional tourism discourse as well as communicative-pragmatic conventions of the production of texts of various genres is considered as a logical way to create a model of effective linguistic branding logistics.

In this regard there is a need to develop the concept of linguistic support of place branding. In this context the creation of a tourist brand may be considered as a system of consecutive linguistic operations which are subject to the principal aim of carrying out tourist branding.

Linguistic support of a region's branding should be based on providing a successful communication through the use of linguosemiotic branding signs. A region's positive image is primarily secured by image texts featuring tourist attractiveness which is achieved through the use of verbal and non-verbal (graphic, visual) means (Gureeva, Novikova, Mityagina, 2016). Thus, the creation of a tourist brand is a system of consecutive communicative operations in the context of a multilingual, multigenre, discursively variable, terminologically and toponymically standardized regional tourism discourse. In order to understand the particular characteristics of a tourism brand one has to understand the particular characteristics of brand management in general.

It is important to be able to differentiate a product brand from a service brand, although "brand" papers sometimes include controversial / incomprehensive / nontransparent definitions. For example, G. Hedrich defines brand as any product or service having a name and other elements encouraging recognition among consumers and image formation (translated by V. Mityagina).

,jedes Angebot (Konsumgut, Dienstleistung, Investitionsgut), das mit einem Markennamen und zusätzlich mit festen Markenelementen gekennzeichnet ist, das den Angehörigen der Zielgruppe und weiterer Bezugsgruppen bekannt und mit einem ausgeprägten, unverwechselbaren Markenbild (Image) versehen ist.“ (Haedrich, 2003: 16).

J. Graumann slightly differentiates between product brand and service brand and defines the latter as a sign used to name a product whose production requires a set of time and space factors fulfilled by a service recipient upon direct contact with its producer. „Zeichen, das der Kennzeichnung von Gütern dient, deren Produktion die unmittelbare raumzeitliche Integration eines externen Faktors in Form der Person des Leistungsnehmers oder seines Verfügungsobjektes in den Leistungsprozess erfordert und die daher ausschließlich im Rahmen eines synchronen Kontaktes zwischen Leistungsgeber und Leistungsnehmer beziehungsweise deren Verfügungsobjekten produziert werden können“. (Graumann, 1983: 84). Service and product brands perform various functions. The functional nature of the product brand may be considered from three viewpoints. From the point of the producer it performs profitability, image formation and information functions. From the point of industry it 
produces an economic effect and performs innovations and profitability functions. From the point of the consumer it performs trust, guidance, identification and prestige functions. The service brand may also be considered from these three viewpoints, but there are also some differences. The service provider has image formation and innovations as his top priorities, for the intermediary it is demand for the service, and for the consumer - trust and security.

The tourist brand is a somewhat symbiosis of the service and product as in this case branding is aimed at such complex entities as regions and municipalities which, being the products of the society's sociolization, render various services to the society and develop positive image promotion strategies.

\section{Urban brand management}

Place branding is a complex multimodal and multifaceted process containing several components:

- Increasing of the region's economy.

- Increasing of the tourist destination attractiveness.

- Marketing activities among residents.

- The advertising and promotion of the region.

- City marketing.

- Establishment marketing.

- Increasing of the region's image.

The listed components give the grounds to assume that marketing is the leading tool of brand management. The concept of marketing proposed by German researcher U. Funke includes five basic types of marketing promoting branding:

- Regional marketing, and mainly the marketing of cities as large urban centers (Standortmarketing).

- Marketing potential of tourism (Tourismusmarketing).

- City-marketing.

- Event-marketing.

- Administrative marketing of territorial entities' leaders (Verwaltungsmarketing) (Funke, 2005: 145-159).

Tourism as a driving factor of economic development, cooperation and interaction on the transnational level and as a factor of transformation, consolidation and formation of national and cultural global values seems to be one of the most effective components of brand management. The formation of tourism discourse reflects the socio-cultural development dynamics: the increase in free time, change of values and improvement of living standards made tourism one of the manifestations of the multinational society's readiness not only for dialogue and integration but also for globalization as tourism makes possible the coexistence of cultures in an individual's experience (Mitjagina, Novikova, Charfaoui, 2017).

According to German sociologist and culturologist M. Thiem, tourism is a combination of several cultural spaces:

- Die Kultur der Quellregion. The culture of the tourists' native region, i.e. a combination of axiological, cultural and behavioral peculiarities of a person living in a certain geographical location with certain historical realia.

- Die Ferienkultur. The culture of behavior on vacation which is set by tourists and the tourism industry conventions.

- Die Dienstleistungskultur. The culture of service rendering represents common norms and rules of the host party's hospitality and the work of tourism industry's representatives. 
- Die Kultur der Zielregion. The culture of the tourist destination region includes norms and rules of behavior, values etc. of the visited region's local population (Thiem, 1993).

In other words, tourism as a clash of "local" and "alien" within tourism discourse creates a new syncretic and convergent space based on a specific destination as the place of travel. Therefore, strategies and tactics of the positioning of tourist attractive places play an important role in transcultural globalized marketing place branding activities.

The development of tourism clusters in specific regions intensifies economic, social and cultural processes, promotes the involvement of residents (local population) and potential tourists (international and regional), shapes the image and brand of an attractive destination (Romadina, Mityagina, 2017). Destination being the starting point in the formation of a tourist product or service integrates a combination of culturally based senses, categories, phenomena, contributors etc. that are related to the region's image or brand. It is well known that $a$ vacation place, municipality, region, country or continent may represent a tourist destination.

The strategic planning of cities as travel places, shaping of positive images and consolidation of brands are becoming increasingly important nowadays.

Any territorial entity with the city as a source of knowledge being the most important one serves as the tourist magnet. The city is some sort of a center of tourist attraction which combines local national and cultural dominants and global leisure elements. Urban cultural tourism has been gaining momentum on an annual basis and has been part of numerous international, all-Russian and regional programs. The city has multiple channels of interaction with the outside world due to the transport infrastructure, intercultural relations, communications etc., and since this type of tourism is economically effective and has socio-cultural significance, socio-economic and marketing urban development strategies are becoming increasingly important. Urban tourism as well as urban intercultural tourism are one of the oldest forms of travel which nowadays integrate such discourses as official discourse, cultural discourse, everyday discourse, administrative discourse etc., and that speaks in favor of the fact that urban tourism is acquiring the features of other types of tourism and, of course, requires a more careful consideration of its particular characteristics from various research viewpoints. In order to understand the discursive nature of urban tourism, let us take as a fundamental viewpoint of German researches H. Neuenfeld and $\mathrm{O}$. Rose who consider a city tour as a combination of the following components:

- Sightseeing tour.

- Event tourism.

- Visiting of the city to spend the evening.

- Visiting of the city to do the shopping.

- Personal business trip.

- Visiting of the city to attend a meeting.

- Attending of congresses or conferences.

- Visiting of fairs.

- Visiting of the city to improve health.

- $\quad$ Pilgrimage (Neuenfeld, 1997).

At the era of globalization the cultural space of modern cities and creation of a tourist attractive image of the city as a tourist destination play a key role in an attempt to attract investors and increase the regions' economic attractiveness. Urban tourism development promotes the cultural transfer as it integrates global processes and local independent spaces having no boundaries for intercultural exchange and 
promoting new social transformations both informatively and formally. In the prism of intercultural tourism cities represent a "here and now" world, the understanding of global cultural trends and the local perspective development.

According to I. Balderjahn, brand formation includes linguistic and extralinguistic components (Balderjahn, 2004):

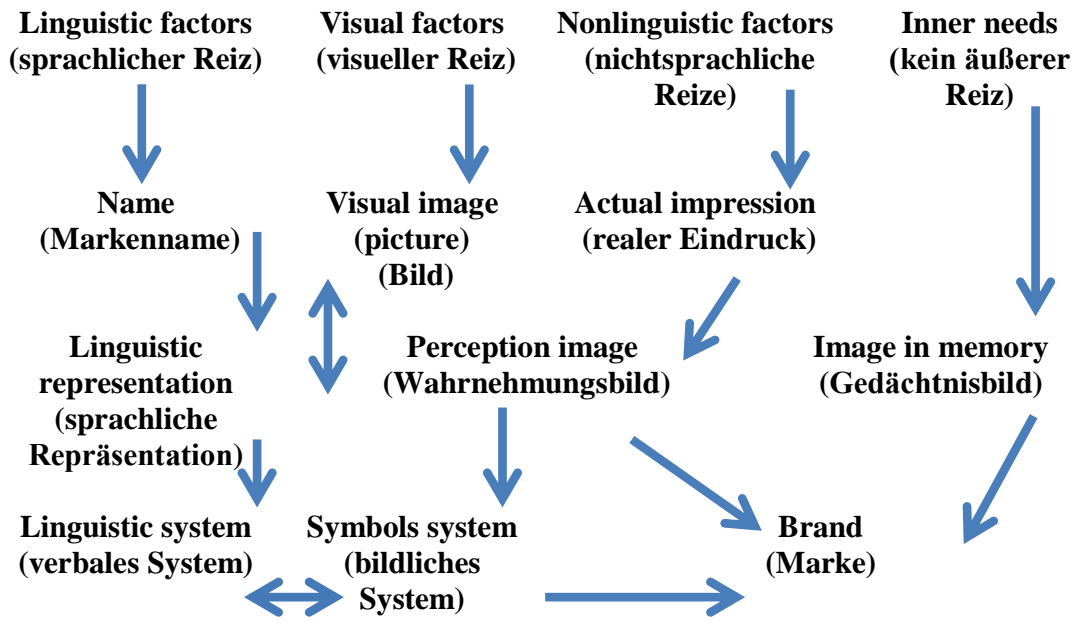

This chart clearly shows that the visual and linguistic components represent the brand's symbiosis. Nonetheless, we suppose that learning about an "alien" city begins with accompanying names and those lying within it. That is why it makes sense to go on to consider linguistic characteristics of branding.

\section{Axiology of branding as a communicative process}

According to V.I. Karasik, it is the language as a system of signs that reveals limitless opportunities for the generation and consolidation of senses. At that, its rich universum is structured in terms of culture as the axiological world picture which determines our understanding of reality (Карасик, 2012: 5). Brand in its broad sense is a trademark in combination with emotional and evaluative stereotypes regarding the given product (Карасик, 2010: 40). This interpretation of brand being extrapolated to the analysis of the place marketing discursive space objectifies the need to develop the concept of brand as a carrier of encoded information about the region's main values.

It is noteworthy that successful city and region brands are always aimed not only at tourists but mainly at new residents, investors and qualified experts. Place marketing is also aimed at residents of a specific area who need to know that they live in an interesting, significant and promising place which develops in determination by basic, universal and its own unique values.

Given the pleasant fact that Russia is in the top-10 world's most visited countries $^{1}$ let us refer to the experience of the countries which are also in this top but brand not only particular places but also regions. In Germany it is the marketing of the federal lands.

Let us consider the "primary" components of brand, those being the region's name and its slogan. The current nomination processes related to the abbreviation

${ }^{1}$ http://www.e-unwto.org/doi/pdf/10.18111/9789284418725

XLinguae, Volume 11, Issue 2, April 2018, ISSN 1337-8384, eISSN 2453-711X 
common in the German language basically create logos which are successfully used in various contexts and are easily recognized and productive: $B B$ - Brandenburg, NINiedersachsen, SL - Saarland, BE - Berlin, NRW - Nordrhein-Westfalen etc. Like a number of the Hanseatic League cities such federal lands as Bremen and Hamburg (Hansestädte) preserved their official hictoric names in the abbreviations $H B$ and $H H$. Let us make a bit of a no-win comparison with the Volgograd Region. The abbreviation $B O(V R)$ has become recognizable only as part of $A B O(A V R)-$ Администрация Волгоградской области (the Administration of the Volgograd Region) within quite a limited field of business communication.

Slogans of the German federal lands do not have a long history and their creation, sometimes change, and survey data reflect the search for an appropriate expression of what is thought to be valuable and important for the positioning of the region and its residents ${ }^{2}$.

The most appropriate slogans, which received more than half of the positive feedback, are those of the four federal lands, namely Schleswig-Holstein, Thuringen, Saarland and Baden-Württemberg.

Schleswig-Holstein's slogan is Der echte Norden which is considered as a loud and clear statement. The True North (hereinfter translated by V. Mityagina), this slogan reflects natural and human resources of the land whose numerous achievements are a result of hard work. It interesting to look at the contradistinction of this geographical nice and popular name of a federal land to the old slogan of BadenWürttemberg Wir sind Süden / We are the South. This nomination missing an evaluative component was favored by less than $20 \%$ of residents. Its current slogan is Wir können alles - Außer Hochdeutsch / We can do everything, except speak standard German. It reprsents potential, pride and self-irony of Germans who in fact speak a difficult dialect. According to the survey, it is the mostly favored slogan.

The surveyed Germans said the slogan of Thuringia, Hier hat Zukunft Tradition / Here the future has tradition, was good, clear and strong.

Saarland, Germany's smallest land is represented by the slogan Großes entsteht immer im Kleinen / Big things always start small.

Neutral statements omitting the reference to socio-cultural values expectedly turned out to be in the middle of the land slogan popularity scale:

Niedersachsen. Klar / Lower Saxony. Clear.

Weil starke Marken nicht viele Worte brauchen. Niedersachsen / Strong brands does not have to be introduced. Lower Saxony.

Wir machen's einfach / We make it easy.

So geht Sächsisch / That's Saxon.

An Hessen führt kein Weg vorbei / All roads lead to Hesse.

These plain modest slogans are indeed welcomed in Eastern lands, although they may sometimes be confusing as to whether such priorities can be expressed. One of the slogans of Saxony-Anhalt, that is Wir stehen früher auf / We get up earlier, reflects the fact that residents of this land start their day 9 minutes earlier than the national average. However, this feature hardly adds to this land's attractiveness. Neither tourists nor new residents to the land are likely to join the early-risers.

The slogans of Berlin and North Rhine-Westphalia represent people's commitment to values and ideals of the Western civilization, globalization and integration:

Be Berlin.

Germany at its best.

These English slogans of Germany's key federal lands are not English by sheer coincidence and getting more popular. The slogan The place to be was

\footnotetext{
${ }^{2}$ http://www.handelsblatt.com/politik/deutschland/umfrage-zu-werbespruechen-das-sind-diebeliebtesten-slogans-der-deutschen-bundeslaender/19493586.html
} 
introduced in Berlin in 2008 through the delivery of 1358205 letters to Berliners who started a campaign for the creation of an attractive image of Berlin on the regional, national and international levels ${ }^{3}$.

Mecklenburg-Vorpommern got a similar German slogan Land zum Leben / The land to live in and later another one which became even popular, MV tut gut / MV does good. The beach basket as a symbol of a comfortable stay became a marketing feature of this land, and the photo of the G8 leaders in such basket on a beach of Heiligendamm in 2007 became the best part of the land's brand. The English slogan Best of Northern Germany, which is important for the branding of MecklenburgVorpommern on the international level, has recently been added to the collection.

It is noteworthy that Germany's slogans get created over various situations and go along with the Hollywood plainness and simplicity which is why the value component becomes simple and unambiguous:

Das Autoland Deutschland.

Deutschland - Land der Ideen.

These slogans may be understood even by those who do not speak German. They represent not only the German peoples' values but also some positive stereotypes about the country like Germany being a country of cars, progress and promising ideas.

Let us point out the first and truly feeble attempts of Russian and Slovak place marketing for comparison. It should be emphasized that such notions as brand, logo and slogan as well as place marketing, brand management and branding are often considered synonyms, and that proves the weakness of branding discourse. Few Russian regions' slogans are far from expressing identical regional socio-cultural values:

Казань - третья столица России (Kazan. The third Russian capital).

Ульяновск - авиачионная столица Poсcии (Ulyanovsk. Russia's aviation capital).

Новосибирск - столица Сибири (Novosibirsk. Siberia's capital).

Нижний Новгород - столица Поволжья (Nizhny Novgorod. The Volga Region's capital).

Добрянка-столииа доброты (Dobryanka. The kindness capital) ${ }^{4}$.

Bratislava - krásavica na Dunaji. ${ }^{5}$

Asfaltová krásavica na Dunaji ${ }^{6}$.

Bratislava-královské mesto ${ }^{7}$.

Moderné mesto na Dunaji ${ }^{8}$.

Mesto Mieru (titul udelený Svetovou radou mieru - WPC)

dikda.eu/wilsonovo-mesto-alebo-krasavica-na-dunajil

Pre mesto v obdobi 19. storočia sú typickým znakom jeho trojjazyčnosti aj jeho tri názvy: Pressburg (nemecky) - Poszony (mad'arsky) -

Prešporok (slovensky), ktoré pretrvali až do začiatku 20. storočia. Od roku 1919 teda Bratislavu Bratislavou nazývame ${ }^{9}$.

\footnotetext{
${ }^{3}$ https://www.sei.berlin.de/

${ }^{4} \mathrm{https}$ ://republic.ru/economics/10_territorialnykh_brendov_rossii-820899.xhtml

${ }^{5} \mathrm{https}: / /$ cestovanie.pravda.sk

${ }^{6}$ https://dennikn.sk/486506/asfaltova-krasavica-dunaji/

${ }^{7}$ https://www.visitbratislava.com/sk/.../bratislava-krasavica-na-dunaj/

${ }^{8}$ https://www.visitbratislava.com/sk/sluzby/bratislava-krasavica-na-dunaj/

${ }^{9}$ http://dikda.eu/wilsonovo-mesto-alebo-krasavica-na-dunaji/
} 
Kedysi honosný slogan „, Krásavica na Dunaji“, ktorý sa už žial’ nepouživa, mohol byt' už dávno nahradený iným: „, Bratislava - mesto krásnych nábrežných promenád" "lo.

Of course, all the best in a country is related to capitals, and this sort of the regions' positioning reflects the value to be the center of something, and this orientedness is reflected in Russian and Slovak regions' nominations. Even the slogan Ненеикий автономный округ - североевропейская кладовая России (Nenets Autonomous Region. Russia's Eastern European treasure trove) is related to the claim to be an undisputed leader in a particular sphere. The same brand based on the concepts of leadership, authority and uniqueness is being developed for Moscow: Столииа - международный культурный центр (The Capital. An international culture center).

Slovak brand nominations often appeal to the royal origins of a historicaal territory: Nitra - matka slovenských miest; Agrokomplex Nitra - centrum slovenského polnohospodárstva;Královské mesto Prešov, Královské mesto Levoča https://www.researchgate.net/publication/312212333_Vnimanie_mesta_Nitra_navstev nikmi [accessed Oct 11 2017].

Neglecting the means to express linguistic and cultural values inherent to the collective consciousness and the collective unconscious of the region's society leads to making ridiculous decisions. For example, one foreign agency drew up a new logo for Saint-Petersburg featuring a lion's head and signed it with the slogan Никаких медведей. Только красота (No bears. Just beauty). This variant was not supported and got rejected. The status of Russia's culture capital being part of SaintPetersburg's brand became, for all its odiousness, a kind of a lifesaver sparing the fact that the slogan represents foreign negative stereotypes and not values and priorities.

\section{Brand naming of the city in tourism discourse}

Brand name and its related nominations are the most important components of branding, and naming is one of the basic branding techniques. The study of brand names represents the initial basis of understanding the branding effectiveness in general. Naming in tourism industry is an interesting research problem which opens new horizons in the place brands analysis. Particular aspects of urban branding are considered in papers by A.A. Egorov (the brand of the City of Pskov), V.N. Stepanov (the brand of the City of Yaroslavl), E.A. Lugovaya and D.B. Lugovoy (the image of the City of Stavropol), A.N. Syrkina and A.S. Shevchenko (the brand of SaintPetersburg) and others.

According to A.O. Chernyakina, the following serve as branding objects:

- The city's style (logo, outdoor advertising, printing, souvenirs, Internet).

- The public transport (airports, train and bus stations, bus stops, and metro including stations, trains, maps, tickets etc.).

- The city navigation (maps and signs).

- The city's sights (museums, exposition centers, parks).

- The city environment (city's objects).

- The event arrangement (City Day, holidays, festivals) (Chernyakina, 2012: 50).

In other words, the city has an inexhaustible branding potential which forms its image and perception by people of national and other cultures.

It also seems appropriate to compare brand nomination of the two twin cities, Volgograd and Chemnitz, contained in the presentations published on the

\footnotetext{
${ }^{10} \mathrm{https}: / / \mathrm{www}$.bakurier.sk/aktualne-dianie/clanok-bratislava-si-zasluzi-mat-atraktivne-nabreznepromenady-plany-a-vizie-2-c
} 
website of Chemnitz ${ }^{11}$ which aside from German has English, French, Spanish, Czech and Polish language versions. The text about Volgograd is presented in Russian (the Russian version was probably provided by the administration of Volgograd) and German in the Power Point format ${ }^{12}$ (). Unfortunately, the official website of Volgograd $^{13}$ exists only in Russian, and the information about the twin cities is presented very briefly and has a reference to the date of signing of the agreement and the link to the website:

Хемнити (Германия). Договор подписан 6 мая 1988 года в Карл-Марксштадте первым заместителем председателя горсовета И.П. Быстровым и обербургомистром, доктором Эберхардом Лангером. Обербургомистр госпожа Барбара ЛЮДВИГ 9008 Хемнити ФРГ тел. 371 / 4881900 факс. 371 / 48819 99. Oberbürgermeister Mrs.Barbara LUDWIG 09008 Chemnitz BRD (the spelling is taken from the website $-\mathrm{V}$. Mityagina) ${ }^{14}$ ).

Let us consider the nominations from the presentation of Volgograd. The translated text is pragmatically adapted and includes original unit translations as well as inserted nominations provided for by the synthesis of information from the original text:

- административный иентр Волгоградской области (the administrative center of the Volgograd region) / das Verwaltungszentrum des Wolgograder Gebietes

- самый длинный город России (Russia's longest city) / eine der längsten Städte Russlands

- $\quad$ один из крупнейших промышленных иентров Юга России и Поволжья (one of the largest industrial centers of Russia's South and Volga region) / eins der größten Industriezentren im Süden von Russland und in der WolgaRegion insgesamt

- культурный центр Волгоградской области (the culture center of the Volgograd region) / das Kulturzentrum des Wolgograder Gebietes

- $\quad$ крупный образовательный центр ЮФО и Нижнего Поволжья (a large educational center of the South Federal District and the Lower Volga region)

- $\quad$ мощнный энергетический узел (a powerful energy hub)

- $\quad$ ein bedeutendes Sportzentrum

It should be noted that the presentation is official and obviously neutral and that it being addressed to the German audience does not contain such the most common nomination as Volgograd is a Hero City. However, similar texts about Volgograd are widely spread on the Internet, and the listed nominations present one of the 15 Russian million cities neutrally and almost routinely. The website of Chemnitz has another text similar to the abovementioned brief summary from the site of the Administration of Volgograd ${ }^{15}$.

This German text matching the style of the website contains effective sociopragmatic comments and evaluative nominations about Volgograd:

Die wechselvolle Geschichte der Stadt spiegelt sich in besonderer Weise in ihren verschiedenen Namen wider / The turbulent history of the city is specifically reflected in its various names (translated by V. Mityagina).

\footnotetext{
${ }_{12}^{11} \mathrm{http}: / / \mathrm{www} . c h e m n i t z \cdot d e /$ chemnitz/de/

http://www.chemnitz.de/chemnitz/media/download/stadt_chemnitz/partnerstaedte/wolgograd.pdf

${ }^{13} \mathrm{http}: / /$ www.volgadmin.ru

${ }^{14} \mathrm{http}: / / \mathrm{www}$. volgadmin.ru/d/about/TwinCities

${ }^{15} \mathrm{http} / / /$ www.chemnitz.de/chemnitz/de/die-stadt-chemnitz/partnerstaedte/wolgograd/
}

XLinguae, Volume 11, Issue 2, April 2018, ISSN 1337-8384, eISSN 2453-711X 
Heute ist Wolgograd eine aufstrebende Metropole und ein bedeutendes industrielles Zentrum Süd-Russlands / Today's Volgograd is a developing megapolis and a large industrial center of Russia's South (translated by V. Mityagina).

The adjectives with a positive connotation (vielseitig, gigantisch, intensiv, weltbekannt, gewaltig, interessant etc.) in this 1500 character text reflect the aim of the website to create a positive image of Chemnitz's twin city as Chemnitz itself is Stadt der Moderne / The modern city (translated by V. Mityagina).

Chemnitz versteht sich als Stadt der Moderne. Weil sich Vergangenheit und Zukunft hier in produktiver Spannung begegnen. Und weil Moderne für uns eine Lebenshaltung ist. I Chemnitz is presented as a modern city because the past and the future exist in harmony here and becuase development is our way of life (translated by V. Mityagina).

The presentation of Chemnitz on the website is an address by Lord Mayor Barbara Ludwig to all city's visitors, everyone interested and potential partners published in the section Stadtportrait / The city's portrait. The section where the project Die Stadt bin ich / I am the city ${ }^{16}$ is presented plays a significant role among the contents of the website. Chemnitz's residents present here everything new: business projects, culture projects, education projects, technology projects etc. The modern city is continually modernized up to nostalgia stores offering Eastern Germany-style products, and the key nomination Stadt der Moderne represents this firm readiness for innovations, and the aspiration to go along with the changing needs. It is noteworthy that the information about changes in the city's architecture, museums and other sights is presented in the context of continuous development and looking into the future, and even such minor fact that Chemnitz is the place where the thermos was invented proves its modernness.

A set of marketing, information and linguistic tools used in the brand promotes the creation of a favorable tourist environment for national and international tourists. At that, the brand's social and linguocultural pragmatics depends on the audience. Urban branding aimed at national tourist service consumers is important for expanding travel horizons as well as has ideological importance, i.e. expanding knowledge about one's own culture and consolidation of culturally and historically significant markers in the national world picture, for example:

- Мыликин - город купеческих домов и музеев (Myshkin is the city of merchant houses and museums $)^{17}$

- Die Altstadt von Quedlinburg: Die Residenz des Reichsgründers ${ }^{18}$

Foreign tourists rather relate city brands to marketing, the attraction of investments, expansion of partner relations, positioning of the city in global tourism discourse:

- $\quad$ Sankt Petersburg wird häufig als das Venedig des Nordens bezeichnet ${ }^{19}$

- Volgograd ...ein Ort der Versöhnung ${ }^{20}$.

- Prešov - Atény nad Torysou ${ }^{21}$

- Mesto Košice - európske hlavné mesto kultúry $2013^{22}$

\footnotetext{
${ }^{16}$ www.die-stadt-bin-ich.de

${ }^{17} \mathrm{http}: / /$ po-svetu-na-kolesax.ru/

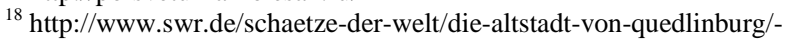
$/ \mathrm{id}=5355190 / \mathrm{did}=5979090 / \mathrm{nid}=5355190 / 1 \mathrm{rg} 97 \mathrm{w} 1 /$ index.$h \mathrm{html}$

${ }^{19} \mathrm{http}: / / \mathrm{www}$.osteuropa-reisen.net/sankt-petersburg-das-venedig-des-nordens/1607/

${ }^{20}$ http://www.auswaertigesamt.de/DE/Infoservice/Presse/Reden/2015/150502_Rede_BM_Er\%C3\%B6ffnung_Friedenskonz ert_Wolgograd.html

${ }^{21} \mathrm{http}: / /$ pis.sk/clanok/8/historia_presova-ateny_nad_torysou_1848_-_1918.html

22 https://euractiv.sk/fokus/regionalny-rozvoj/kosice-europske-hlavne-mesto-kultury-2013000295/
} 
At that, it is important to emphasize that urban branding is a powerful tool for the creation of a so-called touristic gaze (Urry, 1990 ). According to John Urry, such gaze is focused on particular visual signs which formed in the mind of the tourist long before the travel and which are based on other tourists' stereotypes, highly creolized information spread by the media, travel agencies etc. Visual identification of the brand is mainly represented in its graphic and linguistic form. The brand name of the city as well as names of urban infrastructure objects being a combination of semiotic codes should have a series of such features as integrity and pragmatic value, visuality and virtuality, emotivity and emogenicity, recognizability and recoupment. Thus, it seems appropriate to pay special attention to the issue of naming as a linguistic problem in the system of urban brand formation. Naming is a long-century process including a set of language means and naming strategies. The naming sphere of the city consists of its names in various contexts as well as objects included in the urban space. The analysis of Russian and German cities' naming peculiarities allowed to single out the following most productive verbal means.

\section{The use of set precedent names:}

- Köln ist "Die Domstadt" - und doch noch viel mehr; Köln ist nicht umsonst die Hauptstadt des Karnevals ("Fastelovend") in Deutschland ${ }^{23}$

- Ihre Bezeichnung ,Elbflorenz“ verdankt die Stadt... ${ }^{24}$

- Die Barockstadt (Dresden ... $)^{25}$

- Неслучайно центр Северной Пальмиры и связанные с ним архитектурные памятники включены в список объектов Всемирного наследия ЮНЕСКО» (It is not an accident that the center of Northern Palmira and its related architecture monuments are included on the UNESCO World Heritage List $)^{26}$

- MAGIE.TAGE in der Fauststadt Knittlingen ${ }^{27}$

- Das nordfriesische "Holländerstädtchen" Friedrichstadt wird auch Venedig des Nordens genannt. ${ }^{28}$

The use of names representing the city's specific nature:

- Frankfurt am Main, die dynamische und internationale Finanz- und Messestadt mit der imposantesten Skyline Deutschlands. ${ }^{29}$

- Кведлинбург: город-музей (Quedlinburg is a museum-city $)^{30}$

- $\quad$ Мышкин - город мыши (Myshkin is the city of the mouse) ( $^{31}$

- Wolgograd ist die Stadt der Helden 32

- Волгоград признан «Территорией побед» (Volgograd has been recognized as the Territory of Victories) ${ }^{33}(2$

\footnotetext{
${ }^{23} \mathrm{http}: / /$ www.koeln.de/tourismus/stadtfuehrungen/koelner_highlights_327941.htm

${ }^{24} \mathrm{http}: / /$ www.dresden-tourist.de/

${ }^{25} \mathrm{http}: / / \mathrm{www}$. dresden-informationen.de/

${ }^{26} \mathrm{https}: / / \mathrm{www}$. smileplanet.ru/russia/sankt-peterburg/

${ }^{27} \mathrm{http}: / /$ faustmuseum.de/magie-tage-2017-fauststadt-knittlingen/

${ }^{28} \mathrm{https}: / / \mathrm{www} . \mathrm{shz} . \mathrm{de} /$

${ }^{29} \mathrm{https} / / / \mathrm{www}$. frankfurt.de/sixcms/detail.php?id=stadtfrankfurt_eval01.c.124836.de

${ }^{30} \mathrm{http}: / /$ www.nashi-progulki.ru/ru/list/article.php?id=3259

${ }^{31} \mathrm{http}: / /$ citybranding.ru/myishkin-on-nastoyashhiy/

${ }^{32} \mathrm{http}: / /$ www.auswaertiges-

amt.de/DE/Infoservice/Presse/Reden/2015/150502_Rede_BM_Er\%C3\%B6ffnung_Friedenskonz ert_Wolgograd.html

${ }_{33}$ http://www.welcomevolgogradcity.com/News.aspx?idn=395
} 
- Волгоград - это и символ патриотизма и мужества (Volgograd is a symbol of patriotism and courage $)^{34}$

- Die Stadt der Grachten zählt 18 Brücken, die über Sielzüge und Wasserläufe führen. ${ }^{35}$

- $\quad$ Nitra - Európske mesto športu 2018.

- Žilina - Mesto s tvárou.

- Liptovský Mikuláš - Mesto pre všetkých.

- Rožňava - Mesto s výhl'adom.

- Martin - srdcom slovenské, duchom európske hlavné mesto kultúry. ${ }^{36}$

\section{The use of similes:}

- Наш город часто называют сибирским Чикаго. Действительно, мь похожи и по темпам развития. (Our city is often called the Siberian Chicago. In fact, the cities develop at similar rates) ${ }^{37}$

- Во все времена Волгоград, словно Феникс, возрождался из пепла... (Volgograd has always risen as the phoenix rises from the ashes) ${ }^{38}$

- Wolgograd selbst ist ein einziges großes historisches Denkmal für alle sowjetischen Menschen ${ }^{39}$

- $\quad$ Die Stadt] wurde zum Synonym für apokalyptische Zerstörung ${ }^{40}$ ()

- Dank des weder von Krieg noch Zerfall beeinträchtigten Stadtbildes und der großen architektonischen Vielfalt trägt Bamberg auch den Beinamen „Fränkisches Rom" "4l.

\section{The use of metonymy:}

- Кведлинбург - колыбель Германии (Quedlinburg is Germany's crib) ${ }^{42}$.

- Всемирное наследие: Фахверковый город Кведлинбург (World Heritage: the Fachwerk city of Quedlinburg $)^{43}$

- Zdravé mesto Košice 44

The use of various forms of adjectives with emphasizing semantics:

- Rothenburg ob der Tauber gilt als die mittelalterlichste Stadt Deutschlands ${ }^{45}$

- $\quad$ Trier / Rheinland-Pfalz. Deutschlands älteste Stadt fasziniert Besucher aus aller Welt ${ }^{46}$

\footnotetext{
${ }^{34}$ http://tour-rizm.ru/news/turisticheskij_volgograd/2016-11-07-9469

${ }^{35}$ https://www.shz.de/

${ }^{36}$ www.slovenskyturizmus.skhttp

${ }^{37}$ http://www.gorn.pro/archive/2013/5/1934989/

${ }^{38} \mathrm{http}: / /$ lhtravel.ru/chto-posmotret-v-volgograde-dostoprimechatelnosti.html

39 http://www.eu-asien.de/Russland-Informationen/Wolgograd/\%C3\%9Cbersicht/Stadt-

Wolgograd.html

${ }^{40}$ https://www.dresden.de/de/leben/stadtportrait

${ }^{41} \mathrm{http} / / /$ www.rp-online.de/leben/reisen/deutschland/die-schoensten-und-sehenswertestenaltstaedte-deutschlands-bid-1.2904792

${ }^{42}$ http://www.quedlinburg.de/media/pdf/prospekte/prospekt_ru.pdf

${ }^{43} \mathrm{http}: / / \mathrm{www} . \mathrm{dw} \cdot \mathrm{com} / \mathrm{ru} /$

44 http://www.zzke.sk/pre-pacientov/uzitocne-informacie/sutaze/vytvarna-sutaz-2016-zdravemesto-kosice2/

${ }^{45}$ http://www.rp-online.de/leben/reisen/deutschland/die-schoensten-und-

sehenswertesten-altstaedte-deutschlands-bid-1.2904792)

${ }^{46}$ http://www.rp-online.de/leben/reisen/deutschland/die-schoensten-und-sehenswertestenaltstaedte-deutschlands-bid-1.2904792
} 
- ... besitzt Bamberg die größte und am besten erhaltene Altstadt Deutschlands ${ }^{47}$

- Bratislava - Malé Velké Mesto - Little Big City. ${ }^{48}$

\section{Conclusions}

A short analysis of sociopragmatics of naming as the most important component of urban branding in the official information space of tourism discourse allows us to state that the name of the city as the center of a tourist destination in the creation of content aimed at the increasing of the city's attractiveness as a tourist object is crucially important. Place marketing is related to all aspects of branding as a communicative process, and the results of various linguistic research on branding may contribute to resolving pressing economic issues.

As part of the research the authors concluded that a region's successful brand slogan is a motto expressing the society's strengths, perspective, selfconfidence and confidence in the future. Linguistic and cultural values are explicated in the brand slogan in accordance with the aims depending on the level of a tourist destination positioning, that is regional, national and global.

The conducted research allowed us to reveal the following linguistic characteristics of brand-naming:

1) The effectiveness of regional city marketing depends on communicative linguistic strategies of naming.

2) The city's naming sphere includes city's names in various contexts as well as urban space objects.

3) Linguistic support of urban branding is characterized by the use of stylistically marked text elements (tropes, emotional and evaluative words, precedent names).

The study of region branding successful techniques aimed at various kinds of tourism in various languages is an undoubtedly thought-provoking topic. The development of the concept of branding will encourage the effective promotion of new tourism services (extreme tourism, historical tourism, gastronomic tourism, fishing tourism etc.).

This research was conducted with the financial aid from the Russian Foundation for Basic Research (RFBR), the Administration of the Volgograd Region, Project No. 1714-34001 Regional Tourism As Factor of Discourse and Translation Technology Formation: Nominative and Communicative-Pragmatic Conventions of Branding Texts (Volga Lands in the History and Culture of Russia 2017 Regional Contest, Volgograd Region) and the Slovak research agency KEGA 056 PU-4/2016.

\section{Bibliograpic references}

ANHOLT, S. 2007. Competitive Identity: The New Brand Management for Nations, Cities and Regions. Palgrave Macmillan UK. - 160 p. ISBN : 978-0-230-50028-0.

ANHOLT, S. 2009. Places: Identity, Image and Reputation. Palgrave Macmillan UK. - 256 p. ISBN : 978-0-230-23977-7.

ANHOLT, S. 2011. Beyond the Nation Brand:The Role of Image and Identity in International Relations// Exchange: The Journal of Public Diplomacy: Vol. 2 : Iss. 1, Article 1. ISSN: 2325-8543.

\footnotetext{
${ }^{47}$ http://www.rp-online.de/leben/reisen/deutschland/die-schoensten-und-sehenswertestenaltstaedte-deutschlands-bid-1.2904792

${ }^{48}$ http://www.mzv.sk/sk/cinnost_ministerstva/verejna_diplomacia
} 
ANHOLT, S. - HILDRET, D. 2010. Brend Amerika. M.: Dobraya kniga. ISBN: 9785-98124-405-6.

ASADOV, B.R. - BARANOV A.S. O 2017. vliyanii molodezhnogo turizma na formirovanie imidzha territorii kak instrumenta «myagkoy silyi» v kontekste sovremennyih mezhdunarodnyih otnosheniy. In: Vestnik Volgogradskogo gosudarstvennogo universiteta. Seriya 4. Istoriya. Regionovedenie. Mezhdunarodnyie otnosheniya. - 2017. - T. 22, \# 2. - S. 137-148. ISSN (Print): 1998-9938.

BALDERJAHN, I. 2004. Standortmarketing - Ein Konzept zur erfolgreichen Vermarktung von Städten und Regionen. Vortrag auf dem Workshop „Standortentwicklung und - marketing für Gemeinden, Städte und Regionen“ Zürich, 14. Mai 2004, Available online: https://www.unipotsdam.de/marketing_1s/dmdocuments/Praxis\%20und\%20Projekte/Vortraege/Balder jahn/zuerich2004.pdf

BRENDING TERRITORIY. 2013. Luchshie mirovyie praktiki / pod red. Keyta Dinni. M.: Mann, Ivanov i Ferber. ISBN: 9785916576559.

BURMANN, C. - ZEPLIN, S. 2005. Building brand commitment: A behavioural approach to internal brand management. Journal of Brand Management, 12, 4, pp. 279-300. ISSN: 1061-0421.

CHERNYAKINA, A.O. 2012.Brending turistskoy territorii: oshibki i klyuchevyie aspektyi sozdaniya $\mathrm{v}$ ramkah klasternogo podhoda razvitiya // Vestnik TGPU (TSPU Bulletin). Vyip. 12 (127). Tomsk. S. 47-52. ISSN: 1609-624X.

DINNIE, K. 2007. Nation Branding: Concepts, Issues, Practice Taylor \& francis. ISBN-10: 075068349X.

DOBRUCKA, L. et al. 2007. Strategicky rozvojovy plan obce. Bratislava: Peter Macuga-PEEM. ISBN 978-80-89197-77-4

EGOROV, A.A. 2014. Nomen i brend: pskovskij blending v kontekste obshhih problem brendinga territorij/ Filologicheskie nauki. Voprosy teorii i praktiki. Izdatel'stvo: Obshhestvo s ogranichennoj otvetstvennost'ju Izdatel'stvo "Gramota". Tambov. s. 69-71. ISSN: 1997-2911.

FLOREK, M. - INSCH, A. - GNOTH, J. 2006. City council websites as a means of place brand identity communication//Place Branding, 2(4), 276. ISSN: 1751-8040.

FUNKE, U. 2005. Standtkonzeption, Stadtmarketing und City- Management. In: Hochstadt, Stephan (Hrsg.) Stadtentwicklung mit Stadtmanagement? VS Verlag für Sozialwissenschaften. Wiesbaden. S. 145-159. ISBN: 978-3-322-80668-0

GRAUMANN, J. 1983. Die Dienstleistungsmarke. Charakterisierung und Bewertung eines neuen Markentyps aus absatzwirtschaftlicher Sicht. München: VVF Verlag.

GUREEVA, A. A. - NOVIKOVA, E. Y. - MITYAGINA, V. A. 2016. Guideinterpreter's language identity as an excursion discourse factor, Xlinguae, Vol. 10, Issue 2. pp. 90-102. ISSN: 1337-8384.

HAEDRICH, G. - TOMZCAK, T. - KAETZKE, PH. 2003: Strategische Markenführung. 3., vollständig überarbeitete, erweiterte und aktualisierte Auflage. Bern: Haupt Verlag. ISBN: 3-8252-1544-X.

HANULAKOVA, E. 2004. Marketing uzemia. Oblasti, moznosti a perspektivy. Bratislava: Ekonom. ISBN 80-88984-82-3

HASPROVA, M. 2007. Marketing regionu. Bratislava: Progressus Slovakia. ISBN 978-80-969642-53

HILDRETH, J. 2013. The joys and sorrows of logos and slogans in place branding. Place Branding and Public Diplomacy, vol. 9(4), pp. 217-222. doi: 10.1057/pb.2013.28 ISSN: 1751-8040.

HOSPERS, G. J. 2010. Lynch's The Image of the City after 50 Years: City Marketing Lessons from an Urban Planning Classic. European Planning Studies, vol. 18(12), pp. 2073-2081. ISSN: 0965-4313 Online ISSN: 1469-5944. 
INSCH, A. 2014. Positioning cities: Innovative and sustainable strategies for city development and transformation. Place Branding and Public Diplomacy, vol.10 (4), pp. 249-252. ISSN: 1751-8040.

KARASIK, V.I. 2010. Yazyikovaya kristallizatsiya smyisla. Volgograd: Paradigma. ISBN: 978-5-903601-30-1.

KARASIK, V.I. 2012 Yazyikovaya matritsa kulturyi. Volgograd: Paradigma. ISBN: 978-5-903601-59-2.

KUBYISHKIN, A.I. - TSVETKOVA, N.A. 2010. Publichnaya diplomatiya SShA. M: Aspekt Press. ISBN: 978-5-7567-0691-8

LUGOVAJA, E.A,, LUGOVOJ, D.B. 2016. Pozicionirovanie regiona kak sostavnaja chast' brendinga territorii/ brending kak kommunikativnaja tehnologija xxi veka. Materialy II Vserossijskoj nauchno-prakticheskoj konferencii s mezhdunarodnym uchastiem. pod red. A. D. Krivonosova. Izdatel'stvo: Sankt-Peterburgskij gosudarstvennyj jekonomicheskij universitet. - Sankt-Peterburg. pp. 101-103. ISBN: 978-5-7310-3431-9.

LYULKO, A.N. 2011. Kontseptualnyie aspektyi formirovaniya imidzha goroda // Imidzh Rossii: gorod, region, strana: materialyi nauchnoy konferentsii kafedryi rossiyskoy politiki fakulteta politologii MGU imeni M.V. Lomonosova 1noyabrya 2011 g. M.: Izdatel VorobYov A.V., 2011. ISBN: 978-5-93883-177-3.

MITYAGINA, V.A. - NOVIKOVA, E.YU. - CHARFAOUI, E. 2017. Pragmatika terminologicheskoy nominatsii: turisticheskiy menedzhment// XLinguae, Volume 10, Issue 3. pp. 285-299. ISSN: 1337-8384-285.

NEUENFELDT, H., ROSE O. 1997. Stadttourismus als Wirtschaftsfaktor in Aachen. Göttingen: Universität Göttingen.

OLSAVSKY, F. 2012. The importance of marketing research in territorial units brand management. In: Trendy budovania a riadenia znacky II. Bratislava: Comenius University in Bratislava, 2012, pp. 79-86. ISBN 978-80-223-3342-9

OPALKOVA, J. 2013. Konzekutivne tlmocenie 3 : Sprievodcovstvo. Presov : Filozoficka fakulta Presovskej univerzity v Presove, 136 s. ISBN 978-80-555-0785-9. PAULICKOVA, R. 2005. Regionalny a mestsky marketing. Bratislava: Eurounion. ISBN 80-88984-04-1.

ROMADINA, I.D. - MITYAGINA, V.A. 2017. Translation and localization of microtoponyms (based on Russian and English language texts of online tourism discourse)// Xlinguae, vol. 10, Issue 2. pp. 112-124. ISSN: 1337-8384.

SMOLKOVA, E. - STARCHON, P. - WEBEROVA, D. 2016. Country-of-origin brands from the point of view of the Slovak and Czech consumers. In: Proceedings of the 27th International Business Information Management Association Conference Innovation Management and Education Excellence Vision 2020: From Regional Development Sustainability to Global Economic Growth, IBIMA, pp. 2119-2130. ISBN : 978-0-9860419-6-9

STEPANOV, V.N. 2010. Imidzhmejking sovremennogo goroda cherez iventy: $\mathrm{k}$ 1000-letiju goroda jaroslavlja/ IDO SCIENCE. Izdatel'stvo: Centr razvitija sovremennyh obrazovatel'nyh tehnologij. - Moskva. pp. 34-40. ISSN: 2220-8771.

SYRKINA, A.N. - SHEVCHENKO, A.S. 2016. Brending goroda: znachimost' dlja turistov/ brending kak kommunikativnaja tehnologija XXI veka. Materialy II Vserossijskoj nauchno-prakticheskoj konferencii s mezhdunarodnym uchastiem. pod red. A. D. Krivonosova. Izdatel'stvo: Sankt-Peterburgskij gosudarstvennyj jekonomicheskij universitet. - Sankt-Peterburg. pp. 117-121. ISBN: 978-5-7310-34319.

THIEM, M. 1994. Tourismus und kulturelle Identität : die Bedeutung des Tourismus für die Kultur touristischer Ziel- und Quellgebiete Tourismus und kulturelle Identität : die Bedeutung des Tourismus für die Kultur touristischer Ziel- und Quellgebiete. Bern: Berner Studien zu Freizeit und Tourismus. ISBN: 3-9520485-1-8.

XLinguae, Volume 11, Issue 2, April 2018, ISSN 1337-8384, eISSN 2453-711X 
TSUMAROVA, E.YU. 2006. Obraz Karelii: sootnoshenie glavnyih sostavlyayuschih // Vestnik Evrazii, \#2. Pp. 154-170. ISSN: 1727-1770.

URRY, J. The Tourist Gaze: Leisure and Travel in Contemporary Societies. London: Sage. 1990. ISBN-10: 0803981821.

VASILENKO, I.A. i dr. 2012. Imidzh Rossii: kontseptsiya natsionalnogo i territorialnogo brendinga. M.: Ekonomika. ISBN: 978-5-282-03238-3.

VASILENKO, I.A. i dr. 2013. Imidzhevaya strategiya Rossii v kontekste mirovogo opyita. M.: Mezhdunarodnyie otnosheniya, 2013. ISBN: 978-5-7133-1493-0.

VILCEKOVA, L. 2014. Slovak Consumers' Attitudes toward Foreign versus Domestic Brands. Journal of Marketing Management, 2(1): 33-42. ISSN: 2333-6080 (Print), 2333-6099 (Online).

YAKOVLEV, M.V. 2006. Formirovanie politicheskogo imidzha regiona v usloviyah sovremennoy Rossii (na materialah respublik Bashkortostan i Tatarstan). Diss. ... k.p.n. M.: MGU.

Words: 6692

Characters: 46749 (25,97 standard pages)

Prof. Vera A. Mityagina, DrSc. (Philology)

Department of Translation Theory and Practice

Institute of Philology and Intercultural Communication

Volgograd State University

Prospect Universitetsky, 100, 400062, Volgograd

Russia

tipp@ volsu.ru

Assoc. Prof.Elina Yu. Novikova, PhD (Philology),

Department of Translation Theory and Practice

Institute of Philology and Intercultural Communication

Volgograd State University

Prospect Universitetsky, 100, 400062, Volgograd

Russia

tipp@volsu.ru

Assoc. prof. Emilia Charfaoui, $\mathrm{PhD}$ (Philology)

Comenius University in Bratislava

Faculty of Management

Odbojárov 10, P.O.BOX 95, 82005 Bratislava 25

Slovak Republic

Emilia.Charfaoui@fm.uniba.sk

Assoc. prof. Jarmila Opalková, CSc. (Philology)

University in Preshov

Institute of Russian language

U1. 17. novembra, 1, 08001 Prešov

Slovak Republic

jarmila.opalkova@unipo.sk 